\section{Commentary: Don't leave patients to their own devices: Consider long-term complications after percutaneous atrial septal defect closure}

Neel K. Prabhu, BSE, Joseph W. Turek, MD, PhD, and Nicholas D. Andersen, MD

Percutaneous device closure of atrial septal defects (ASDs) was introduced in the late 1990s as a feasible alternative to surgical repair. ${ }^{1}$ Since then, several studies have shown that short-term outcomes and complication rates after percutaneous ASD closure are noninferior to those after surgery. ${ }^{2,3}$ However, an important consideration with percutaneous ASD closure is the prevalence of late complications that have come to light after its widespread adoption. Some of these, including cardiac erosion, thromboembolism, and infective endocarditis, carry significant morbidity and mortality. Kitamura and colleagues ${ }^{4}$ present a case report of a 20 -year-old man with atopic dermatitis and a secundum ASD who was treated with Amplatzer device (Abbott, Abbott Park, Ill) closure and developed endocarditis with large mobile vegetations 3 years later. The authors concluded that ASD closure devices are associated with risks of thrombotic and infectious complications over the long-term. ${ }^{4}$

Kitamura and colleagues ${ }^{4}$ should be commended for publishing this interesting report. They provide context for their work and discuss a complication which holds relevance for

From the ${ }^{\mathrm{a}}$ Duke Congenital Heart Surgery Research \& Training Laboratory and ${ }^{\mathrm{c}} \mathrm{Di}-$ vision of Thoracic and Cardiovascular Surgery, Duke University Medical Center, Durham, NC; and 'Duke Children's Pediatric \& Congenital Heart Center, Duke Children's Hospital, Durham, NC.

Disclosures: The authors reported no conflicts of interest.

The Journal policy requires editors and reviewers to disclose conflicts of interest and to decline handling or reviewing manuscripts for which they may have a conflict of interest. The editors and reviewers of this article have no conflicts of interest.

Received for publication Feb 4, 2021; revisions received Feb 4, 2021; accepted for publication Feb 4, 2021; available ahead of print Feb 9, 2021

Address for reprints: Nicholas D. Andersen, MD, Division of Thoracic and Cardiovascular Surgery, Duke University Medical Center, 2301 Erwin Rd, DUMC 3443, Durham, NC 27710 (E-mail: nicholas.andersen@ duke.edu).

JTCVS Techniques 2021;7:242-3

2666-2507

Copyright (c) 2021 The Authors. Published by Elsevier Inc. on behalf of The American Association for Thoracic Surgery. This is an open access article under the CC BY-NCND license (http://creativecommons.org/licenses/by-nc-nd/4.0/).

https://doi.org/10.1016/j.xjtc.2021.02.015

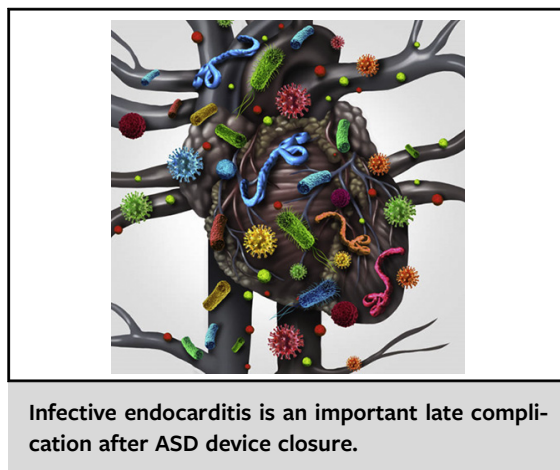

CENTRAL MESSAGE

Patients undergoing percutaneous closure of atrial septal defects require close monitoring for late complications such as infective endocarditis, cardiac erosion, and valve damage.

primary care providers, interventional cardiologists, and cardiovascular surgeons alike. In addition, the authors describe well the preoperative findings and operative techniques used to address the lesion. However, additional details about the medical and social history of the patient, such as comorbidities and history of intravenous or inhaled substance use, could possibly elucidate additional characteristics of the high-risk patient. Furthermore, the authors do not quantify from either their personal experience or literature review the prevalence of ASD device complications.

It is intriguing that several case reports describe the same complication of late endocarditis after ASD device deployment. ${ }^{5-7}$ As Kitamura and colleagues ${ }^{4}$ describe, a likely explanation for this pathology is poor endothelialization of the device and resultant exposure of bare prothrombotic metal that could also provide a surface for bacterial adhesion. Although endocarditis is relatively rare after ASD device placement, with approximately 20 cases reported in the literature to date, it carries significant morbidity and mortality because more than $85 \%$ of these patients required surgery and $11 \%$ experienced operative mortality. ${ }^{8}$ Other analyses have reported several other long-term complications after ASD device placement, such as cardiac erosion, nickel hypersensitivity, and valve damage, all of which often present suddenly and are potentially lethal. ${ }^{9}$ Although there are no differences in shortterm complication rates between surgical and device ASD 
closure, ${ }^{3}$ similar sudden late complications after surgery are relatively rare.

Although percutaneous ASD closure has become the preferred treatment at many centers due to the shorter recovery and less invasiveness, it is important to carefully follow patients long-term after ASD device closure. This is especially important for those vulnerable patients with underlying immunocompromise, syndromic comorbidities, or metabolic derangements. In addition, patients with risk factors for endocarditis certainly may be better served with a traditional surgical repair, which remains the gold standard for ASD closure.

Kitamura and colleagues ${ }^{4}$ should be commended for their contribution to the literature on a late complication of percutaneous ASD closure. Indeed, after undergoing this procedure, patients should not be left to their own devices!

\section{References}

1. Masura J, Gavora P, Formanek A, Hijazi ZM. Transcatheter closure of secundum atrial septal defects using the new self-centering Amplatzer septal occluder: initial human experience. Cathet Cardiovasc Diagn. 1997;42:388-93.
2. Jones TK, Latson LA, Zahn E, Fleishman CE, Jacobson J, Vincent R, et al. Results of the U.S. multicenter pivotal study of the HELEX septal occluder for percutaneous closure of secundum atrial septal defects. J Am Coll Cardiol. 2007;49: 2215-21.

3. Thomson JD, Aburawi EH, Watterson KG, Van Doorn C, Gibbs JL. Surgical and transcatheter (Amplatzer) closure of atrial septal defects: a prospective comparison of results and cost. Heart. 2002;87:466-9.

4. Kitamura H, Yamamoto M, Kagase A. Mobile vegetations on a poorly endothelialized atrial septal defect closure device. J Thorac Cardiovasc Surg Tech. 2021;7: 240-1.

5. Slesnick TC, Nugent AW, Fraser CD Jr, Cannon BC. Images in cardiovascular medicine. Incomplete endothelialization and late development of acute bacterial endocarditis after implantation of an Amplatzer septal occluder device. Circulation. 2008;117:e326-7.

6. Nguyen AK, Palafox BA, Starr JP, Gates RN, Berdjis F. Endocarditis and incomplete endothelialization 12 years after Amplatzer septal occluder deployment. Tex Heart Inst J. 2016:43:227-31.

7. Jha NK, Kiraly L, Murala JS, Tamas C, Talo H, El Badaoui H, et al. Late endocarditis of Amplatzer atrial septal occluder device in a child. World J Cardiol. 2015;7: 703-6.

8. Amedro P, Soulatges C, Fraisse A. Infective endocarditis after device closure of atrial septal defects: case report and review of the literature. Catheter Cardiovasc Interv. 2017;89:324-34.

9. Jalal Z, Hascoet S, Baruteau AE, Iriart X, Kreitmann B, Boudjemline Y, et al. Long-term complications after transcatheter atrial septal defect closure: a review of the medical literature. Can J Cardiol. 2016;32:1315. e111315.e18. 